\title{
3 Research Square

\section{Wind-driven Advection Across Temperature Gradients Supports Phytoplankton Blooms in the Iron-limited Antarctic Polar Front}

Frederico Brandini ( $\boldsymbol{\sim}$ brandini@usp.br )

Oceanographic Institute of São Paulo University,

\section{Adrienne Silver}

University of Massachusetts Dartmouth, School for Marine Science and Technology, Department of Estuarine and Ocean Sciences

\section{Avijit Gangopadhyay}

University of Massachusetts Dartmouth, School for Marine Science and Technology, Department of Estuarine and Ocean Sciences

\section{Research Article}

Keywords: wind-driven Ekman transport, northern Polar Front (PF) belt, temperature-controlled growth

Posted Date: November 25th, 2020

DOI: https://doi.org/10.21203/rs.3.rs-109517/v1

License: (c) (i) This work is licensed under a Creative Commons Attribution 4.0 International License. Read Full License 


\section{Abstract}

We demonstrate how the wind-driven Ekman transport enhances the advection and mixing of cells from the colder waters of the Surface Antarctic Waters from the south to the warmer waters of the northern Polar Front (PF) belt. This mechanism provides cells a mean ambient temperature near optimum levels for species-specific and, ultimately, community growth rates high enough to develop blooms under nonlight limiting, macronutrients and iron conditions. A Lagrangian trajectory model was constructed for tracking plankton cells as tracers forced by winds and surface currents. We argue that wind-driven Ekman drift of surface currents can carry phytoplankton cells into warmer waters and thus increase their growth rates to potentially generate blooms, even under iron-limiting conditions. Depending on the region along the circumpolar front, increased winds can enhance this process, and further accelerate such temperature-controlled growth.

\section{Introduction}

The upper layers of the global ocean are commonly occupied by frontal systems with physical and/or biogeochemical gradients on a wide range of spatial scales $[\mathbf{1}, 2]$. They play an important role in pelagic ecosystem processes due to the exchange of biologically limiting properties between adjacent water masses and are sites of elevated primary productivity, biodiversity, and fisheries [3, 4]. Oceanic fronts contribute towards the diagenesis of ocean floor sediments and ultimately the carbon sink on a wide basin scale [1, 5]. The Subtropical Convergence (STC, 38-40囚S) and the Polar Front (PF, 50-65囚S) are two of the most conspicuous oceanic fronts of the Southern Ocean (SO), appearing in global climatological maps as hydrodynamic boundaries between subtropical, sub-Antarctic, and Antarctic water masses [6, 7, 8].

Diatoms usually dominate phytoplankton assemblages in oceanic fronts $[9,10,11]$ making them important sites of atmospheric carbon uptake, hence contributing to the oceanic biological pump [5]. Biogeochemical processes in the euphotic zone of wide and hydrographically homogeneous water masses, are radically altered in frontal zones. For example, heating exchange increases water column stability and the input of macronutrients (mostly nitrate and silicate) from the nutrient-rich Sub-Antarctic region into the adjacent nutrient-poor waters of the Subtropical Gyre. This turns the STC into an ideal environment for the accumulation of diatoms $[9,12]$. The PF represents a sharp north-south surface temperature gradient usually between 2-6 $\mathbb{} \mathrm{C}$, with a mean width of $43 \mathrm{~km}$ depending on bathymetric features and seasonal period $[2,6]$ and high (hence non-limiting) macro nutrient concentrations in both sides of the front $[9,11]$. Both Ekman-driven and geostrophic currents tend to move parcels from colder

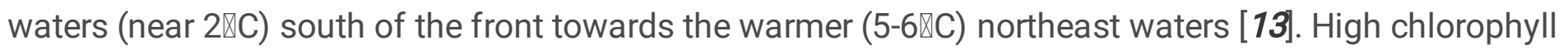
concentrations of more than $0.5 \mathrm{mg} \mathrm{m}^{-3}$ and peak blooms of around $4 \mathrm{mg} \mathrm{m}^{-3}$ have been reported along the front as compared to the range of $0.3-0.4 \mathrm{mg} \cdot \mathrm{m}^{-3}$ reported in the sub-Antarctic zone to the north and in the colder surface waters of the Antarctic Circumpolar Current (ACC) to the south $[10,14,15]$. This makes the PF one of the most productive area in the Southern Ocean and an important site of atmospheric $\mathrm{CO}_{2}$ sequestration [ 5 , and references therein]. 
The acceptance of the hypothesis that iron is the main limiting factor for primary productivity in the HighNutrient-Low-Chlorophyll (HNLC) regions of the Southern Ocean [16], has led to the iron limitation idea becoming a popular, if not the main topic of Antarctic phytoplankton research for over two decades. Field and shipboard iron-enrichment experiments demonstrated the shift of the phytoplankton community composition towards larger macro-sized cells (mostly diatoms), an increase in biomass, and an increase in the physiological performance of the cells with the addition of iron $[\mathbf{1 7}, \mathbf{1 8}, \mathbf{1 9}]$. Hence, the positive effect of iron on the growth rates of phytoplankton has been proposed as the primary mechanism controlling phytoplankton blooms and atmospheric carbon uptake in the PF zone [20, 21].

However, our current understanding of the controls on phytoplankton growth and blooms in polar waters encompasses an interplay of multiple environmental drivers such as iron, light, nutrients (including iron) and temperature $[22,23,24,25,26]$. The question of which of these factors leads to the development of phytoplakton blooms at any given time and position along the front still needs to be revisited. For instance, it is worth noting that the PF blooms respond to iron-enrichment $[17,18,19)$ where the bloom coincides with the optimum temperatures for phytoplankton growth between 5-6囚C have been often reported in the Antarctic literature [22-24, 27). This indicates that (i) polar diatoms are not fully adapted to the ambient temperatures below $2 \mathbb{} \mathbb{C}$ which covers a significant portion of Antarctic surface waters [28] and (ii) the effect of in situ temperature should have been considered in the results of iron fertilization experiments in polar environments. Here we hypothesize that, besides natural or artificial iron inputs, the rising temperature contributes towards increasing diatom growth rates during their Ekman-driven advection across the PF. To test this hypothesis, we first reconstruct a new region-specific growthtemperature regression model within the $0-6 \mathbb{C}$ temperature range, based on data available in the Antarctic literature (Table 1), and then carry out a robust set of cluster-based Lagrangian simulations using circulation fields from a hydrodynamic model reanalysis across the PF zone in six longitudinal sectors [6] of the Southern Ocean, representatives of the three different world ocean basins.

\section{Results}

We used an equation (Eq.1) derived from an exponential empirical regression between phytoplankton growth rate $\left(\mathrm{d}^{-1}\right)$ vs temperature $(\mathbb{} \mathrm{C})$ (see Materials and Methods; Fig.1) available in the Antarctic literature (Table 1). Despite the limited data set, Eq.1 reflects a consistent relationship between growth rate and temperature. This equation was incorporated into a hydrodynamic model showing the potential northeastward transport of a particle representing a phytoplankton cell, along with a mass of colder water from the south limit of the PF (see Fig. 2 for the PF regional boundaries and temperature variation). The model uses the empirical regression equation to calculate phytoplankton growth rates along with the gradient of rising temperature during their trajectory across the front in 6 longitudinal regions (modeling domains in Fig. 3) representing 6 sectors of the Southern Ocean (Fig. 2). These six sectors and their representative regions are: going eastward starting from the Atlantic-Indian sector (Region A), IndianPacific sector (Region B), Central Pacific (Region C), Eastern Pacific (Region D), Pacific-Atlantic (Region E) and Atlantic (Region F). To investigate the role of wind driven forcing on diatoms across the PF a set of 
four numerical experiments were carried out in each section: (i) control, (ii) average wind; (iii) double-wind; and (iv) triple-wind. Each experiment was carried out with a cluster initialization of 100 random seed locations around a starting location in the low-temperature zone (near $2 \bowtie C$ ) within the PF in a regional domain. The results described below are for the average of the cluster simulations for each experiment. Details of model simulations are described in Materials and Methods.

Inspection of the growth rate over time for the first region at the location starting at 15区E and 50खS (Fig. 3 region A and Fig.4a) reveals that the particle starts with a low growth rate of around $0.4 \mathrm{~d}^{-1}$ (corresponding to a temperature of around $2^{\circ} \mathrm{C}$; see Fig.1 and Eq. 1). As the particle begins to move in the average winds experiment, the growth rate increases till about day 8 , after which the growth rate plateaus out at around $0.5 \mathrm{~d}^{-1}$ till around day 15 , after which it begins to increase again. Comparing the different wind-forced trajectories in region A (Fig.3), one can see that the areas in which the particle was moving due to a higher advective flow (forced by the winds) to the north correspond to where the growth rate was increasing at a faster rate. Conversely the areas where the particle moves zonally along latitude circles (weak winds) correspond to where the growth rate is either decreasing or staying constant.

When comparing all the different start locations it becomes evident that the role of wind forcing varies longitudinally. In regions C, E and F, wind appears to play a larger role in particle movement (Fig. 4c, 4e, and $4 f$ ). Regions $E$ and $F$ show large differences between the experiments, with the experiment with stronger winds (for F) showing faster increases in growth rate. Region $\mathrm{C}$ shows little difference between experiments until the wind is tripled when it shows a significantly larger growth rate near the end of the 30-day run. On the other hand, regions $A, B$ and $D$ show relatively little changes with increased wind from their respective control runs. This is because the flows in these regions are predominantly geostrophic. In particular region $\mathrm{D}$, (the seeding place of this cluster was closer to the northern boundary of the PF) shows strong geostrophic flow with the particles in all experiments moving into warmer waters (farther north) than in any other experiments.

Note however that, stronger winds blowing at a non-optimal direction can push the particle back into cooler waters. This could be what caused the dip in growth rate seen in region $\mathrm{F}$ around day 12 in the triple wind experiment (Fig. 4f), where the wind pushed the particle in a more zonal direction causing it to enter cooler waters. Alternatively, wind-forced mesoscale meanders and eddies, which are common in the PF zone [34, 35], may trap cells restricting them to be transported further north. In some cases, eddies or southward flow in the Oscar field were unable to be cancelled out by the winds and the particle would remain almost stationary.

\section{Discussion}

The temperature vs growth rate model (Fig. 1) seems consistent with the common observations of chlorophyll bloom-concentrations across the PF. The circulation model's cluster simulation analysis suggests that the physical-biological interaction of exposing growing diatoms at near optimum ambient 
temperatures by the wind-driven advection process is an important, if not a primary driver for bloom development in the PF in the absence of iron.

Earlier investigations suggested [22] that the Antarctic Surface Water (ASW) could be transported together with diatom cells northwards across the PF thermal gradient, and the hydrodynamics of this transport has been confirmed [13]. Our model demonstrates this might happen in all regions of the circumpolar PF belt. As a validation of the model results, chlorophyll concentration for January of 2019 obtained from NASA Earth Observation site shows the high surface chlorophyll concentrations match well with the northern edge of the PF (Fig. 5), agreeing with the simulated results of our model (Fig. 1).

Results from the numerical modeling sensitivity experiments can be summarized as follows. For all regions, increased winds increased the distance the particles traveled moving them into warmer waters and therefore increasing the growth rate. Some regions, particularly regions $C$, E, and $F$ showed stronger influence of increased winds. This can be seen in figure (Fig. 4a-f) by the increased difference in growth rates between experiments. Region D (Eastern Pacific sector) showed the largest northward transport in all experiments, including the control, showing large geostrophic flows in this region pushing the particles into warmer waters.

In four of the regions, A, D, E and F, (all in the Eastern Pacific through Atlantic-Indian sectors) the winds pushed the parcels into temperature zones over the max threshold of $5^{\circ} \mathrm{C}$ (Fig. $4 \mathrm{a}-\mathrm{f}$ ), corresponding to a growth rate of $K=0.62 \mathrm{~d}^{-1}$ given by Eq 1. For regions $A$ and $D$ the threshold is exceeded in all three experiments. In regions $E$ and $F$ this threshold in only reached in some of the experiments, double and triple wind for $E$ and all experiments apart from the control in F. This indicates a window of opportunity, where growth rate can be maximized before being pushed to unfavorable conditions by strong winds. In region $\mathrm{F}$ the growth rate plateaus right above the threshold for the wind experiments and remains just below the threshold for the control experiment with no wind. This indicates that in region $\mathrm{F}$ phytoplankton drifting across the front would remain at near optimal temperature for most of their journey. This matches well with what is seen in the surface chlorophyll in Figure 5 with region $\mathrm{F}$ (near Drake Passage) being an area of high primary productivity. These regions also have the narrowest band of the PF, which might set up ideal conditions for cells to transverse across the PF to a growth zone of higher temperature.

A limitation of this modelling is that these simulations are done in an idealized manner with average winds and January (summer) conditions only. Future studies can include similar experiments with synoptic realistic winds (which would be much stronger than average winds) and for other months in spring and summer. Additionally, in our model seed locations were selected to avoid the eddies within the geostrophic flow field. These mesoscale eddies are very prevalent within the polar font and have the potential to prevent the particles northward movement. Depending on the temperature of these eddies, this can either be detrimental or beneficial to the phytoplankton growth. In one scenario an eddy trapped a particle at $5^{\circ} \mathrm{C}$, the optimum growth rate, potentially allowing for a bloom to from. In other case the eddies trapped the particles in around $2^{\circ} \mathrm{C}$, not ideal for temperatures for growth. 
Finally, we would like to reiterate the idea of the Polar Front blooms and their mechanistic linkages to the physical and temperature-dependent growth rate in the light of above results and discussion of simulations. Maximum growth rates of the polar diatoms have been reported to occur above the ambient temperature [22-24, 27], meaning molecular and genetic evolution for temperature-dependent growth rate adaptation is still in progress in polar waters. Most shipboard iron-enrichment incubations and field fertilizations demonstrated changes in the phytoplankton composition towards larger macro-sized cells (mostly diatoms), enhanced physiological performance of the cells and the consequent increase of phytoplankton biomass $[17,21,37,38]$. However, culture enrichments with iron did not always give the expected results [21, 39]. Therefore, a more consistent growth rate trend of polar diatoms as a function of temperature and iron availability still needs to be achieved. It is worth noting that the sole addition of iron does not always double the growth rate of polar diatoms [38]. In contrast, temperature does allow for growth, even if increased by just a few degrees above the ambient conditions $[23,24,38,40$, and in ironlimited conditions $[26,38]$. The enhancement of polar diatom growth rates with increasing temperatures has been reported within the usual temperature range of the PF zone $[24,27,26]$. Early investigations calculated up to a $50-100 \%$ increase of photosynthetic rates of natural Antarctic phytoplankton from ambient sub-zero temperatures up to $4-7 \otimes C[22,23]$. Batch cultured diatoms collected in the Weddell Sea

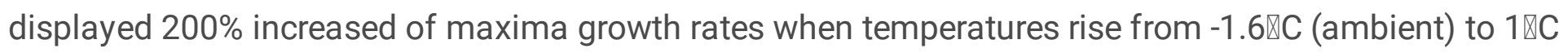
[40].

High chlorophyll concentrations up to $2 \mathrm{mg} \cdot \mathrm{m}^{-3}$ under limiting iron conditions of $0.15-0.45 \mathrm{nM}$ has been reported in the PF of the Atlantic sector justifying that past higher iron availability could have already been incorporated by phytoplankton prior to their sampling survey [10]. The authors [10] also neglected the effect of a small temperature range of just $1.2 \otimes C$ on biomass differences across the front. In fact, this could be the case regarding iron, yet polar diatoms are very sensitive to even slight increases of temperature $[22-26,40]$ and our model predicts that under that temperature range growth rates could have been increased by $0.13 \mathrm{~d}^{-1}$, which would be enough to double cell density in just five days. In addition, it has been reported that Antarctic phytoplankton growth rates in coastal, presumably non-iron deficient, and offshore iron-limited waters tend to be similar if temperature is held constant [39]. A difference of $40 \%$ between the growth rate of iron-replete and iron-deplete cultures was recently reported, yet the effect of temperature increase on the growth of both iron-deplete and iron-replete diatoms was remarkably higher $(60-100 \%)[26,38]$ meaning the effect of temperature on the growth of polar diatoms can be higher than the isolated effect of iron.

Despite a seasonal decrease of $c a 1 \mathrm{nM}$ of iron stock over the upper $100 \mathrm{~m}$ layers across the PF region [20], the left-over of 1-1.5 nM of iron was still above the minimum requirement of 0.2-1.0 nM of oceanic and coastal phytoplankton [41, 42] and within the range of the half-saturation constant $\left(\mathrm{K}_{\mathrm{m}}\right)$ of 0.59-1.12 $\mathrm{nM}$ for iron uptake by polar diatoms [37] and at least $5 x$ times higher than the $K_{m}$ of $0.022 \mathrm{nM}$ and 0.027 $\mathrm{nM}$ found in the northern and southern side of the PF, respectively [21]. In addition, the necessity of iron for the synthesis of the enzyme nitrate reductase increases at lower temperatures [43], suggesting that iron deficiency is alleviated in the warmer northern bound of the PF. High concentrations of chlorophyll in 
cyclonic eddies formed in the PF have been associated with cross-front transport of iron from the south to the north and heat from the north to the south [44]. The authors argued that heat exchange increases the physical stratification of the euphotic zone, reducing simultaneously iron and light limitations, hence favoring phytoplankton growth. Our model simulations suggest that besides iron and non-light limited condition, the increase of mean temperature outside the eddy is an additional driver for the higher phytoplankton growth rates and chlorophyll accumulation in the Antarctic region. As stated earlier, phytoplankton growth needs the simultaneous interaction of multiple drivers [30-33] to balance losses and increase net biomass in any natural environment. Yet for a bloom to develop in the PF growth rates must increase to a level that temperature by itself may provide, independent of iron availability [38]. Our model predicts that phytoplankton bloom development in the PF depends on the wind-driven Ekman transport and the mixing of cold south waters with the warm north waters of the front, providing cells a mean ambient temperature near the optimum levels for growth rates necessary to develop blooms. We demonstrate that the wind field, combined with geostrophic flow in the PF zone, is the main driver exposing diatoms to optimal temperatures on the northern side of the front, enhancing their growth rates over that observed in the colder ASW south of the front. This does not contradict iron limitation on bloom development along the Southern Ocean, particularly along the PF where usual dissolved iron concentration is in fact exceptionally low [45]. It simply demonstrates that the advection of cells across the front turns temperature into an additional factor that may even be more effective than iron for growth rate enhancement, when and where iron is not limiting.

\section{Material And Methods}

We first constructed a temperature vs. growth rate curve (Fig.1) specifically applicable for the Antarctic PF region where surface temperature usually ranges between $0 \otimes C$ and $6 \otimes C[6,7]$. The optimum temperature

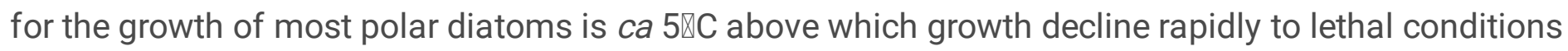
$[24,27,38]$. Therefore, we only include in the model $K$ values obtained up to $5 \bowtie C$ to avoid deviations of the positive relationship between growth rate and temperature. Growth rate ( $K$ in days $\left.{ }^{-1}\right)$ measurements are rarely reported in the Antarctic literature; hence our model is based on an empirical relationship of pairs of $K v s T$ data points obtained from investigations where $K$ of a specific diatom species has been measured at more than one temperature ranging from $0-5^{\circ} \mathrm{C}$. A total of 39 pairs of growth rates and temperature data were assembled (Table 1). Growth rates may be predicted from temperature by the exponential regression equation derived from the temperature vs. growth rate curve shown in Figure 1.

$$
\mathrm{K}=0.2095 \mathrm{e}^{0.2181 \mathrm{~T}}
$$

This equation was used later in the numerical model experiments for determining growth rates at various temperatures along the path of diatoms cells while being advected by winds and circulation across the PF.

\section{Numerical Model Experiments}


The PF exhibits considerable variability in its latitudinal thermal contrast along its path around the Antarctic continent. Six longitudinal sectors (Table 2 and Fig. 2) were chosen for carrying out representative simulations with varying degree of wind on distinct hydrographic/circulation regimes, with three domains bordering the Pacific basin, two domains bordering the Atlantic and one in the Indian basin.

To investigate the role of wind driven forcing on diatoms across the PF a set of four numerical experiments were carried out in each section: (i) control, (ii) average wind; (iii) double-wind; and (iv) triplewind. We used two well-established gridded reanalysis fields, the OSCAR provided by the Earth and Space Research Institute at http://dx.doi.org/10.5067/OSCAR-03D01 and ARMOR3D. These reanalysis fields were used along with a reanalysis of the wind product for developing the control experiment field for January 2019. We run a series of sensitivity studies in each domain by increasing the wind amplitude to two- and three-times the average winds. This set up is explained in detail below. The control circulation field was derived by subtracting the wind-effects from the OSCAR circulation field to obtain a purely geostrophic flow. OSCAR combines a quasi-steady geostrophic model with wind driven ageostrophic and thermal wind adjustment components to obtain sea surface currents at a $1 / 3^{\circ}$ resolution (Fig.2).

The Ekman drift velocities were calculated using the wind speeds (from Remote Sensing Systems) and mixed layer depth available from ARMOR3D, which combines satellites data with in situ temperature and salinity through statistical methods to give mixed layer depth and geostrophic currents fields at a $1 / 4^{\circ}$ resolution [46]. ARMOR3D mixed layer depth was used in the Ekman transport calculations and geostrophic flow was used to qualitatively validate the control simulation fields derived from OSCAR. Wind data was obtained from Remote Sensing System's WindSat Polarimetric Radiometer data for January 2019 , which provided wind velocity at $1 / 4^{\circ}$ resolution [47. From these data sets four different experiments with varying levels of wind forcing were set up (Table 3 ).

The experimental domains were selected based on the variability of the mean PF location in each region [5]. A similar set of wind-forced experiments was repeated within each of the 6 domains. In each geographical region (domain) a start location was first chosen. A cluster initialization was then constructed consisting of 100 randomly generated particle seeding locations within a circular area with $0.25^{\circ}$ radius around the start location. The seeding locations were chosen so that the particles begin their journey on the southern side of the front at around $2-3^{\circ} \mathrm{C}$ surface temperature water. Start locations were also selected to avoid eddies at the beginning so that the particles would be given a change to move north. A simple Lagrangian trajectory model was then constructed to follow the particle from its initial seed location to its subsequent destination as advected by the wind and circulation fields.

The calculation of wind driven Lagrangian trajectories can be explained in five steps. First the particle is dropped on the southern side of the PF. Wind velocity is then fed in at the given location and is used to calculate the wind stress. Advective velocity due to Ekman drift is then calculated from this wind stress and the mixed layer depth (from ARMOR3D) based on a simple Ekman balance. Here, $V_{E k m a n}$ is the surface velocity (assumed to decay linearly to zero at the base of mixed layer), $M_{y}$ is the mass transport 
due to Ekman Drift and given by,$\tau_{\mathrm{x}}$ is the zonal wind stress in the longitudinal direction, $f$ is the Coriolis parameter, $\rho$ is the density of the water $\left(1025 \mathrm{~kg} \mathrm{~m}^{-3}\right)$, and $\mathrm{H}$ is the mixed layer depth. Depending on the experiments these calculated Ekman velocities were then either added to (Expt \# 3 and 4) or subtracted from (Expt \#1) the OSCAR velocities (Expt \#2). The particle is then advected by this resulting velocity on the given trajectory for the one-hour time-step, after which the wind (from RSS), mixed layer depth (from ARMOR3D), and OSCAR velocities are reassessed at the new location for January, 2019. The Lagrangian model is then run for another time-step ( 1 hour) to yield a new advected location of the tracer (cell). This location has a new temperature, which is recorded from the WOA18 fields (see below) and used in the growth model from Equation 1 and plotted in Figure 4a-f. This continues for 30 days, a time interval necessary for a bloom development $[15,35,48]$ from a mean background ambient chlorophyll concentration of $0.2 \mathrm{mg} \mathrm{m}^{-3}$ in most of the Antarctic surface waters south of the PF zone [36] at a mean chlorophyll accumulation rate of $0.027 \mathrm{~d}^{-1}[48]$.

Example of trajectories for each of the regions for the average wind experiment is shown in Figure 3. In most regions the particle moves northeastwards across the front into warmer waters over the lengths of the experiments. This pattern is not clear in domain $\mathrm{B}$ where particles remain almost along the same latitudinal belt, thus within a narrow temperature range, which is not enough to increase the potential growth rate substantially compared to the rate at the starting location. Following each of these particle trajectories, temperature time series were determined using the January climatology temperature field obtained from World Ocean Atlas 18 at https://www.nodc.noaa.gov/OC5/woa18/ with a resolution of $1 / 4^{\circ}$. Finally, the newly developed temperature-growth equation (1) yields the estimated growth rate along the trajectories across the PF in the 6 selected longitudinal sections (Fig. 3).

\section{Declarations}

\section{Acknowledgements}

We would like to acknowledge the support of SMAST and UMass Dartmouth for this study during the visit of FB from IOUSP (Brazil) to SMAST. The WindSat data used in our model was produced by Remote Sensing Systems and sponsored by the NASA Earth Science MEaSUREs DISCOVER Project and the NASA Earth Science Physical Oceanography Program. RSS WindSat data are available at www.remss.com.

Funding: F.B. was supported by the grant no. 88881.313390/2019-01 from the Brazilian Ministry of Education and Culture.

Author contributions: F.P.B. conceived the research idea and wrote the manuscript with support from A.G. A.M.S. performed data calculations, worked with computer analyses, build up the model, and created the figures and tables. A.G. developed the model with support from A.S. and contributed to the discussion and analyses of the results.

\section{References}


1. Longhurst, A. R. Ecological Geography of the Sea. Academic Press, San Diego, ed 2(2006)

2. Belkin, I.M., Cornillon, P.C. \& Sherman, K. Fronts in large marine ecosystems. Prog. Oceanogr. 81, 223-236 (2009)

3. Acha, E.M., Piola, A., Iribarne, O. \& Mianzan, H. Ecological Processes at Marine Fronts.Springer International Publishing, chap.3 (2015)

4. Woodson, C.B. \& Litvin, S.Y. Ocean fronts drive marine fishery production and biogeochemical cycling. Proc. Natl. Acad. Sci. USA 112, 1710-1715 (2015)

5. Ito, T., Woloszyn, M. \& Mazloff, M. Anthropogenic carbon dioxide transport in the Southern Ocean driven by Ekman flow. Nature Letters 463 (2010), doi:10.1038/nature08687

6. Moore, J. K. et al. SeaWiFS satellite ocean color data from the Southern Ocean. Geophysical Research Letters 26, 1465-1468 (1999)

7. Dong, S., Sprintfall, J. \& Gill, S.T. Location of the Antarctic Polar Front from AMSR-E Satellite Sea Surface Temperature Measurements. Journal of Physical Oceanography 36, 2075-2089 (2006)

8. Graham, R. M. \& De Boer, A. M. The Dynamical Subtropical Front. J. Geophys. Res. 118, 5676-5685 (2013)

9. Brandini, F. P. et al. Multiannual trends in fronts and distribution of nutrients and chlorophyll in the southwestern Atlantic (30-62º ). Deep-Sea Research / 47, 1015-1033 (2000)

10. Smetacek, V., Klaas, C., Mewnde-Deuer, S. \& Rynearson, T.A. Mesoscale distribution of dominant diatom species relative to hydrographical field along the Antarctic Polar Front. Deep-Sea Research II 49, 3835-3848 (2002)

11. DiTullio, G. R. et al. Phytoplankton assemblage structure and primary productivity along $170 \mathrm{~W}$ in the South Pacific Ocean. Mar. Ecol. Progr. Series 255, 55-80 (2003)

12. Olguin, H. F., Boltovskoy, D., Lange, C. D. \& Brandini, F. P. Distribution of spring phytoplankton (manly diatom) in the upper $50 \mathrm{~m}$ of the Southwestern Atlantic Ocean (30-60 $\mathrm{S})$. Journal of Plankton Research 28, 1107-1128 (2006)

13. Gnanadesikan, A. \& Hallberg, R. W. On the Relationship of the Circumpolar Current to Southern Hemisphere Winds in Coarse-Resolution Ocean Models. J. Phys. Oceanogr. 30, 2013-2034 (2000)

14. Smetacek, V., de Baar, H. J. W., Bathmann, U. V., Lochte, K. \& van der Loeff, R. Ecology and biogeochemistry of the Antarctic Circumpolar Current during austral spring: a summary of Southern Ocean JGOFS cruise ANT X/6 of R.V. Polarstern. Deep-Sea Research II 44, 1-21 (1997)

15. Bathmann, U.V., Scharek, R., Klass, C., Dubishar, C.D. \& Smetacek, V. Spring development of phytoplankton biomass and composition in major water masses of the Atlantic sector of the Southern Ocean. Deep-Sea Res. 44, p51-67 (1997)

16. Martin, J. H., Fitzwater, S.E. \& Gordon, R. M. Iron deficiency limits phytoplankton growth in Antarctic waters. Global Biogeochemical Cycles 4, 5-12 (1990)

17. de Baar, H. J. W. et al. Synthesis of iron fertilization experiments: from the iron age in the age of enlightenment. J. Geophys. Res. 110, C09S16 (2005) 
18. Boyd, P. W. et al. Mesoscale iron enrichment experiments 1993-2005: Synthesis and future directions. Science 315, 612-617 (2007)

19. Tripathy, S. C. \& Jena, B. Iron-Stimulated Phytoplankton Blooms in the Southern Ocean: A Brief Review. Remote Sensing in Earth Systems Sciences 2, 64-77 (2019)

20. de Baar, H. J. W. et al. Importance of iron for plankton blooms and carbon dioxide drawdown in the Southern Ocean. Nature 373, 412-415 (1995)

21. Coale, K. H., Wang, X., Tanner, S. J. \& Johnson, K. S. Phytoplankton growth and biological response to iron and zinc addition in the Ross Sea and Antarctic Circumpolar Current along $170^{\circ} \mathrm{W}$. Deep-Sea Res. 50, 635-653 (2003)

22. Neori, A. \& Holm-Hansen, O. Effect of Temperature on Rate of Photosynthesis in Antarctic Phytoplankton. Polar Biology 1, 33-38 (1982)

23. Jacques, G. Some Ecophysiological Aspects of the Antarctic Phytoplankton. Polar Biology 2, 27-33 (1983)

24. Fiala M. \& Oriol, M. L. Light-temperature interactions on the growth of Antarctic diatoms. Polar Biology 10, 629-636 (1990)

25. Mitchell, B. G., Brody, E. A., Holm-Hansen, O., McClain, C.\& Bishop, J. Light limitation of phytoplankton biomass and macronutrient utilization in the Southern Ocean. Limnol. Oceanogr. 36, 1662-1677 (1991).

26. Andrew, S M., Morell, H. T., Strzepek, R. F., Boyd, P. W. \& Ellwood, M. J. Iron Availability Influences the Tolerance of Southern Ocean Phytoplankton to Warming and Elevated Irradiance. Frontiers in Marine Science 6, art681 (2019)

27. Coello-Camba, A. \& Agusti, S. Thermal thresholds of phytoplankton growth in polar waters and their consequences for warming polar ocean. Frontiers in Marine Science 4, ra168, (2017)

28. Thomas, M. K., Kremer, C. T., Klausmeier, C. A. \& Litchman, E. A global pattern of thermal adaptation in marine phytoplankton. Science 338, 1085-1088 (2012)

29. Teoh, M.L., Chu, W.L., Marchant, H. \& Phang, S.M. Influence of culture temperature on the growth, biochemical composition and fatty acid profiles of six Antarctic microalgae. Journal of Applied Phycology16, 421-430 (2004)

30. Mortain-Bertrand, A. Effects of light fluctuations on growth and productivity of Antarctic diatoms in culture. Polar Biol. 9, 245-252 (1989)

31. Longhi, M.L., Schloss, I. R. \& Wiencke, C. Effect of irradiance and temperature on photosynthesis and growth of two Antarctic benthic diatoms, Gyrosigma subsalinum and Odontella litigiosa. Bot. Mar. 46, 276-284 (2003)

32. Reay, D. S. et al. Regulation by low temperature of phytoplankton growth and nutrient uptake in the Southern Ocean. Mar. Ecol. Prog. Ser. 219, 51-64 (2001)

33. Tilzer, M.M. \& Dubinsky, Z. Effects of temperature and day length on the mass balance of Antarctic phytoplankton. Polar Biology 7, 35-42 (1987) 
34. Hoepffner, N. Stratégies d'adaptation photosynthétique chez les diatomées de l'Océan Antarctique: variations du nombre et de la taille des units photosynthétiques. J. Plankton Res. 6, 881-895 (1984)

35. Abbott, M.R., Richman, J.G., Nahorniak, J.S. \& Barksdale, B.S. Meanders in the Antarctic Polar Frontal Zone and their impact on phytoplankton. Deep-Sea Research // 48, 3891-3912 (2001)

36. Barth, J.A., Cowles, T.J. \& Pierce, S.D. Mesoscale physical and bio-optical structure of the Antarctic Polar Front near $170^{\circ} \mathrm{W}$ during austral spring. Geophys. Res. 106, 13879-1390 (2001)

37. Timmermans, K.R. et al. Growth rates of large and small Southern Ocean diatoms in relation to availability of iron in natural seawater. Limno. Oceanogr. 46, 260-266 (2001)

38. Boyd, P. W. Physiology and iron modulate diverse responses of diatoms to a warming Southern Ocean. Nature Climate Change 9, 148-152 (2019)

39. Banse, K. Rates of phytoplankton cell division in the field and in iron enrichment experiments. Limnol. Oceanogr. 36, 1866-1898 (1991)

40. Baumann, M. E. M., Brandini, F. P. \& Staubes, R. The influence of light and temperature on carbon specific DMS release by cultures of Phaeocystis Antarctica and three Antarctic diatoms. Marine Chemistry 45, 129-136 (1994)

41. Sunda, W. G., Swift, D. G. \& Huntsman, A. S. Low iron requirement for growth in oceanic phytoplankton. Nature 351, 55-57 (1991)

42. Brand, L. E. Minimum iron requirements of marine phytoplankton and the implications for the biogeochemical control of new production. Limnol. Oceanogr. 36, 1756-1771 (1991)

43. Timmermans, K. R., Stolte, W. \& de Baar, H. J. W. Iron-mediated effects on nitrate reductase in marine phytoplankton. Marine Biology 121, 389-396 (1994)

44. Kahru, M., Mitchell, B. G., Gille, S. T., Hewes, C. D. \& Holm-Hansen O. Eddies enhance biological production in the Weddell-Scotia Confluence of the Southern Ocean. Geophysical Research Letters 34, LI 14603 (2007).

45. Klunder, M. B. et al. Dissolved Fe across the Weddell Sea and Drake Passage: impact of DFe on nutrient uptake. Biogeosciences 11, 651-669 (2014)

46. Mulet, S., Rio, M. H., Mignot, A., Guinehut, S. \& Morrow, R. A new estimate of the global 3D geostrophic ocean circulation based on satellite data and in-situ measurements. Deep Sea Research Part II: Topical Studies in Oceanography 77-80, 70-81 (2012)

47. Wentz, F. J. et al. Remote Sensing Systems Coriolis WindSat [Available online at www.remss.com/missions/windsat] (2013)

48. Landry, M. R. et al. Initiation of the spring phytoplankton increase in the Antarctic Polar Front Zone at $170^{\circ}$ W. Journal of Geophysical Research 106, 13903-13915 (2001)

\section{Tables}

Table 1. Dataset of growth rates of Antarctic diatoms and natural communities growing under different temperature conditions used to develop the exponential temperature-growth rate equation 1. 


\begin{tabular}{|llll|}
\hline Phytoplankton & $\mathbf{T} \mathbf{~} \mathbf{C}$ & $\mathbf{k}^{\left(\mathbf{d}^{-1}\right)}$ & Ref. No \\
\hline Chaetoceros deflandrei & $2-5$ & $0.33-0.88$ & 24 \\
\hline Chaetoceros deflandrei & 5 & 1.05 & 34 \\
\hline Chaetoceros deflandrei & 5 & 1.02 & 34 \\
\hline Chaetoceros sp & $3-5$ & $0.41-0.63$ & 23 \\
\hline Corethron criophilum & 3 & 0.33 & 30 \\
\hline Corethron criophilum & $0-4$ & $0.13-0.38$ & 24 \\
\hline C. pennatum & 4 & 0.25 & 23 \\
\hline F. kerguelensis & $3-5$ & $0.25-0.48$ & 23 \\
\hline Navicula sp & 4 & 0.34 & 29 \\
\hline Nitzschia cylindrus & $0-5$ & $0.27-0.86$ & 24 \\
\hline N. kerguelensis & $0-4$ & $0.3-0.78$ & 24 \\
\hline N. kerguelensis & 4 & 0.52 & 23 \\
\hline N. turgiloides & $1-3$ & $0.25-0.71$ & 24 \\
\hline N. turgiloides & $3-5$ & $0.45-0.44$ & 23 \\
\hline N. turgiloides & 3 & 0.61 & 30 \\
\hline N. turgiloides & 5 & 0.43 & 34 \\
\hline N. turgiloides & 5 & 0.39 & 34 \\
\hline Stellarina microtrias & $1-4$ & $0.42-0.85$ & 24 \\
\hline S. microtrias & 3 & 0.13 & 30 \\
\hline S. microtrias & 3 & 0.18 & 30 \\
\hline S. microtrias & 3 & 0.22 & 30 \\
\hline Synedra sp & $1-5$ & $0.31-0.56$ & 24 \\
\hline Thalassiosira sp & 4 & 0,6 & 27 \\
\hline Thalassiosira sp & 4 & 0,45 & 27 \\
\hline natural community & $2-5$ & $0.54-1.18$ & 32 \\
\hline natural community & $4-5$ & $0.4-0.82$ & 27 \\
\hline natural community & 5 & 0.82 & 33 \\
\hline
\end{tabular}


Table 2. Experimental domains selected within six different sectors for carrying out representative simulations with varying degree of wind on these six different hydrographic/circulation regimes

\begin{tabular}{|lllll|}
\hline $\begin{array}{l}\text { Region } \\
\text { Name } \\
\text { (Sectors) }\end{array}$ & $\begin{array}{l}\text { Longitudinal Extent } \\
\text { of Sectors }\end{array}$ & $\begin{array}{l}\text { Latitudinal range of } \\
\text { Polar Front }\end{array}$ & $\begin{array}{l}\text { Initial Seed } \\
\text { Location }\end{array}$ & $\begin{array}{l}\text { Experimental Domain } \\
\text { Identifier }\end{array}$ \\
\hline $\begin{array}{l}\text { Atlantic- } \\
\text { Indian }\end{array}$ & $50^{\circ} \mathrm{W}$ to $80^{\circ} \mathrm{E}$ & Roughly $50^{\circ} \mathrm{S}$ & $15^{\circ} \mathrm{E}, 50^{\circ} \mathrm{S}$ & $\mathrm{A}$ \\
\hline $\begin{array}{l}\text { Indian- } \\
\text { Pacific }\end{array}$ & $80^{\circ} \mathrm{E}$ to $160^{\circ} \mathrm{E}$ & $50^{\circ}-55^{\circ} \mathrm{S}$ & $120^{\circ} \mathrm{W}, 55^{\circ} \mathrm{S}$ & $\mathrm{B}$ \\
\hline $\begin{array}{l}\text { Central } \\
\text { Pacific }\end{array}$ & $160^{\circ} \mathrm{E}$ to $170^{\circ} \mathrm{W}$ & $60^{\circ}-65^{\circ} \mathrm{S}$ & $175^{\circ} \mathrm{E}, 60^{\circ} \mathrm{S}$ & $\mathrm{C}$ \\
\hline $\begin{array}{l}\text { Eastern } \\
\text { Pacific }\end{array}$ & $170^{\circ} \mathrm{W}$ to $130^{\circ} \mathrm{W}$ & $55^{\circ}-60^{\circ} \mathrm{S}$ & $145^{\circ} \mathrm{W}, 56^{\circ} \mathrm{S}$ & $\mathrm{D}$ \\
\hline $\begin{array}{l}\text { Pacific- } \\
\text { Atlantic }\end{array}$ & $130^{\circ} \mathrm{W}$ to $70^{\circ} \mathrm{W}$ & $60^{\circ}-65^{\circ} \mathrm{S}$ & $100^{\circ} \mathrm{W}, 60^{\circ} \mathrm{S}$ & $\mathrm{E}$ \\
\hline Atlantic & $70^{\circ} \mathrm{W}$ to $50^{\circ} \mathrm{W}$ & $55^{\circ}-60^{\circ} \mathrm{S}$ & $60^{\circ} \mathrm{W}, 58^{\circ} \mathrm{S}$ & $\mathrm{F}$ \\
\hline
\end{tabular}

Table 3. Numerical Model Cluster Simulation Conditions with different wind forcing and OSCAR fields

\begin{tabular}{|lll|}
\hline Experiment & Simulation condition & Data used for comparison \\
\hline 1 & Control & OSCAR - Ekman \\
\hline 2 & Average Wind & OSCAR \\
\hline 3 & Double Wind & OSCAR + Ekman \\
4 & Triple Wind & OSCAR + 2*Ekman \\
\hline
\end{tabular}

\section{Figures}




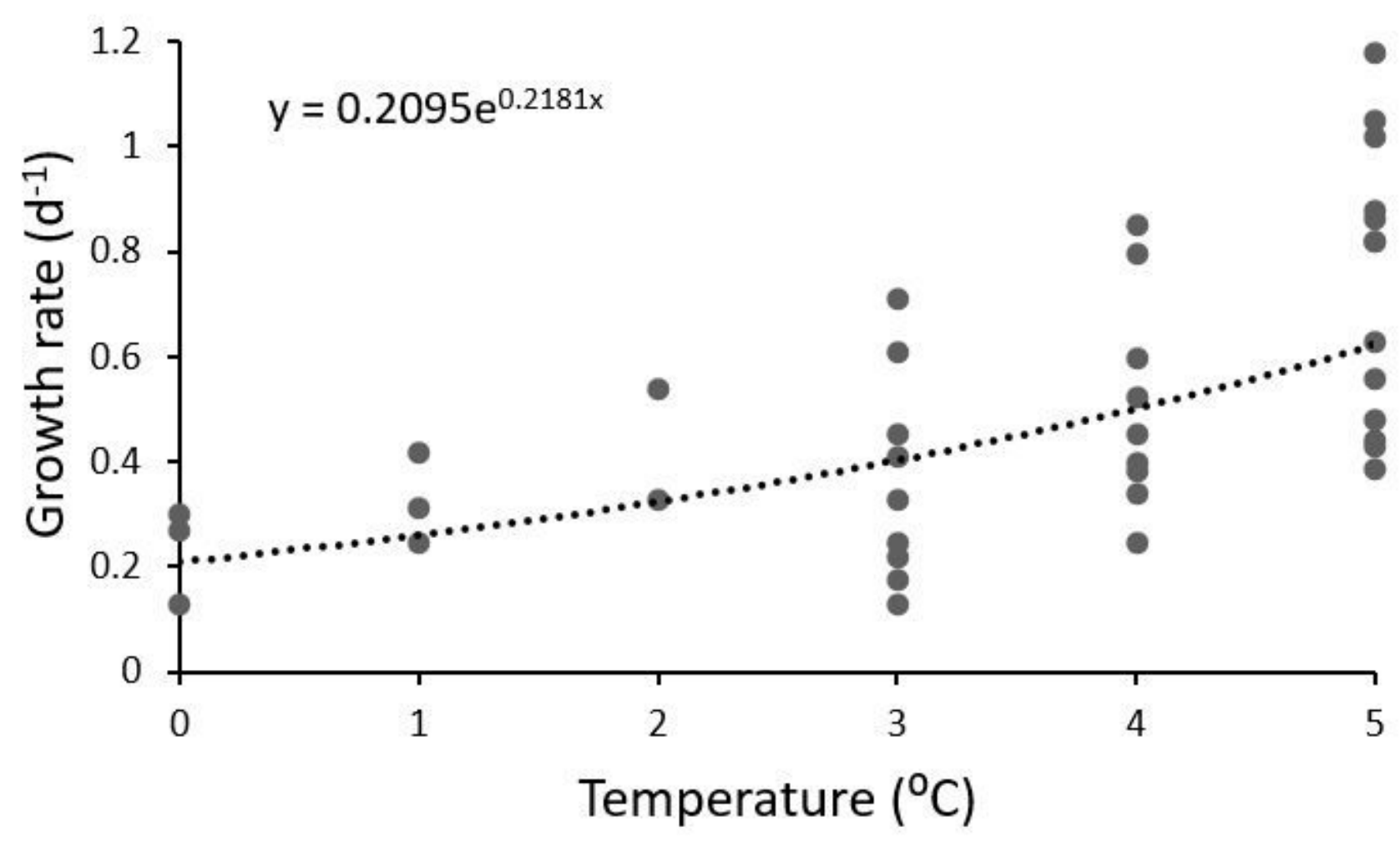

Figure 1

Increasing pattern of specific growth rates of Antarctic diatoms and natural phytoplankton community as a function of temperature within the range of 0 to $5 \bowtie C$. 


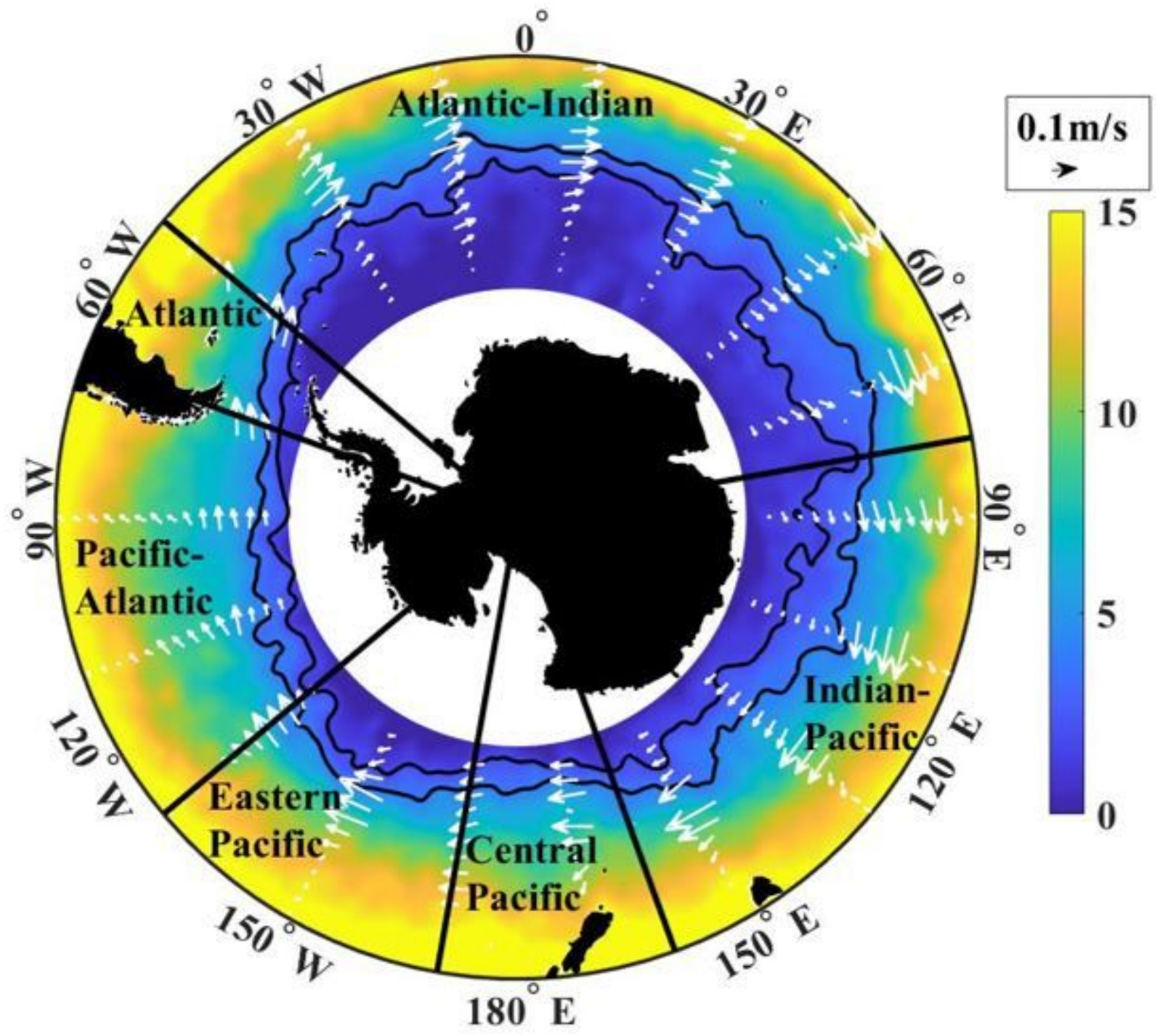

Figure 2

Ocean circulation field (white velocity vectors) around the Antarctic (up to about $45^{\circ} \mathrm{S}$ ) for January 2019 from OSCAR. Background color shows the climatological temperature for January from the World Ocean Atlas [available at https://www.nodc.noaa.gov/OC5/woa18/]. The six sectors based on Moore et al. (6) study characterizes different variability of the Polar Front. Note that the Polar Front is between the $2^{\circ} \mathrm{C}$ and $4^{\circ} \mathrm{C}$ temperature contours in black. See text for details. Note: The designations employed and the presentation of the material on this map do not imply the expression of any opinion whatsoever on the part of Research Square concerning the legal status of any country, territory, city or area or of its authorities, or concerning the delimitation of its frontiers or boundaries. This map has been provided by the authors. 


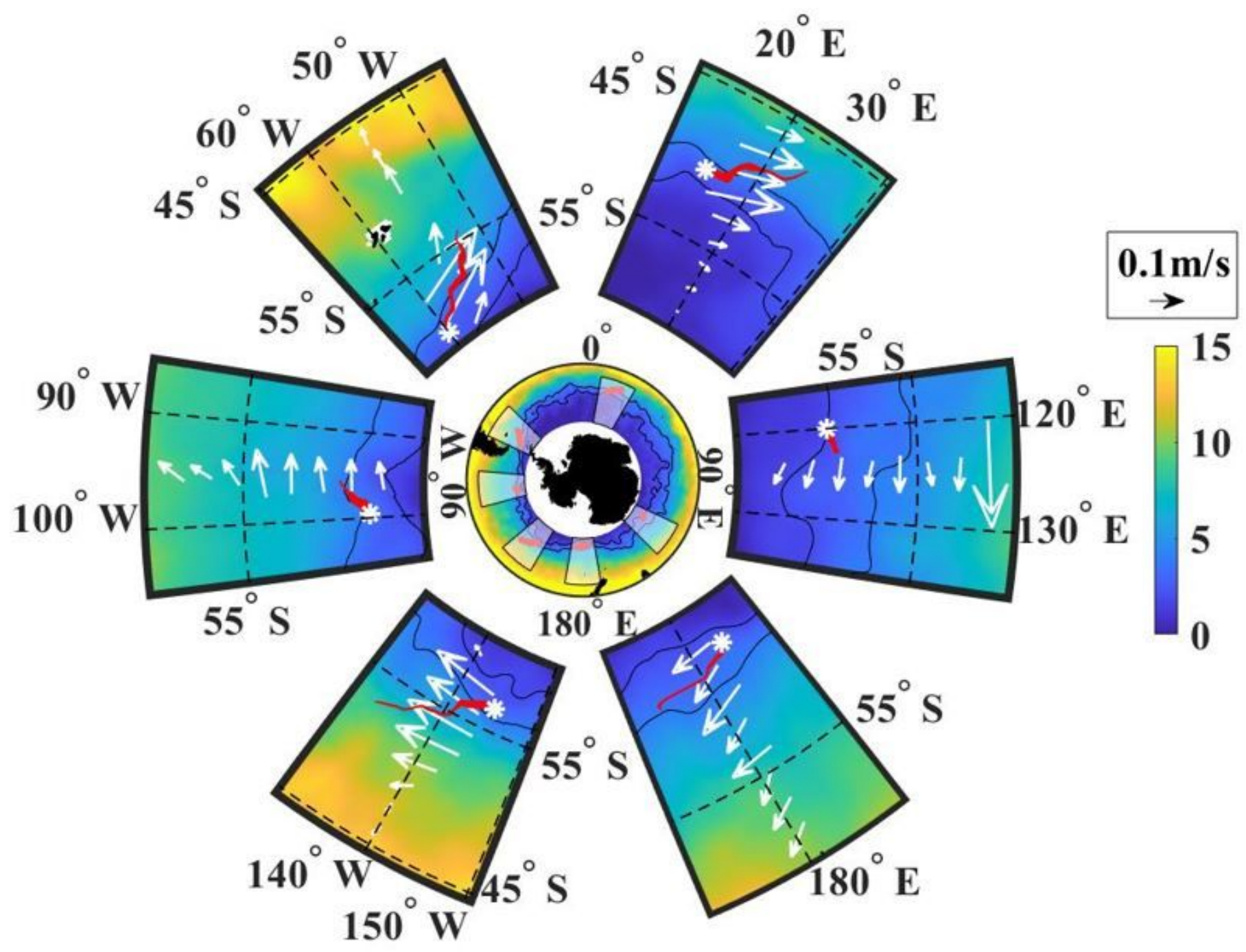

Figure 3

Six different domains for the Polar Front growth rate experimental set-up are shown in the polygons surrounding the inner circle. These six regions are representatives of the typical behavior of the PF temperature/growth contrast in the six different sectors shown in Figure 1. The black dashed North-South lines indicate the longitudes labeled outside the domain near the line. The black contours of 2 and $4{ }^{\circ} \mathrm{C}$ are plotted to show the edges of the polar front. Red lines represent the average lagrangian trajectory for the Experiment 2 (average winds) for all six experiments and derived from a cluster simulation from 100 random starting points around the seed location. White asterisks mark the starting seed locations. White vectors show the Oscar flow field with average winds. In all locations the particle moves north into warmer waters over the length of the experiment. Color bar shows climatological temperature $\left({ }^{\circ} \mathrm{C}\right)$ for the month of January obtained from World Ocean Atlas [available at https://www.nodc.noaa.gov/OC5/woa18/]. Note: The designations employed and the presentation of the material on this map do not imply the expression of any opinion whatsoever on the part of Research 
Square concerning the legal status of any country, territory, city or area or of its authorities, or concerning the delimitation of its frontiers or boundaries. This map has been provided by the authors.
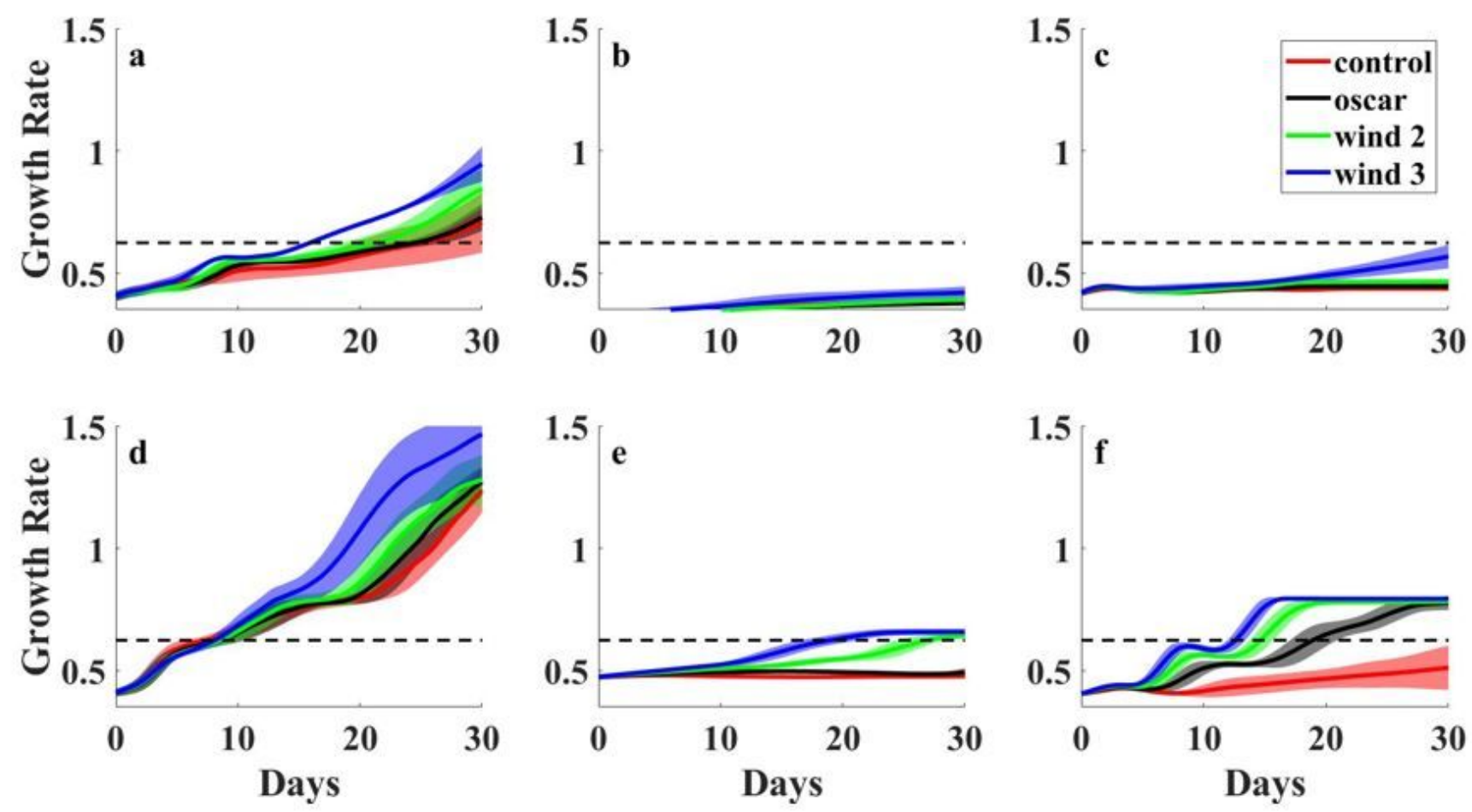

\section{Figure 4}

Model simulated output showing changes in the Antarctic phytoplankton growth rate caused by changes in temperature in the six experimental sectors of the Polar Front. See Table 1 and Figure 2 for details of locations and regions. Solid lines represent the mean growth rate per day of all 100 particles within the cluster. The shaded region represents the mean \pm SEM. The black dashed line at $0.62 \mathrm{~d}-1$ represent the threshold of max growth rate obtained at $5^{\circ} \mathrm{C}$ (derived from the new equation in Fig. 1). 


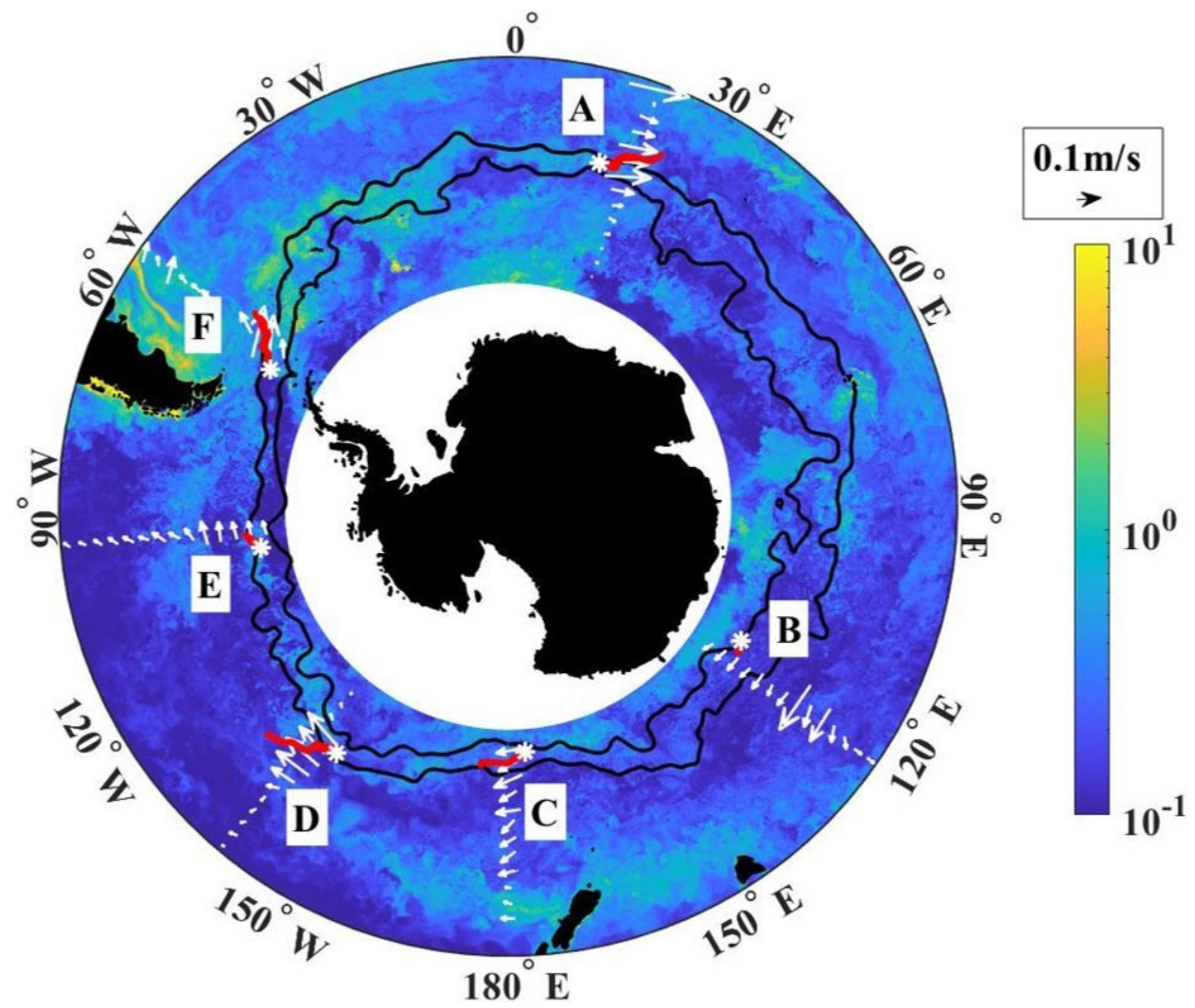

Figure 5

Chlorophyll-a field (mg/m3) for January 2019, obtained from NASA Earth Observations (NEO) at https://neo.sci.gsfc.nasa.gov/view.php?datasetld=MY1DMM_CHLORA. Red lines show Lagrangian trajectories from Experiment 2 with average wind transport for the 6 different regions. The black lines represent the $2^{\circ} \mathrm{C}$ and $4^{\circ} \mathrm{C}$ temperature contours. White vectors show the OSCAR flow field with average winds. Note: The designations employed and the presentation of the material on this map do not imply the expression of any opinion whatsoever on the part of Research Square concerning the legal status of any country, territory, city or area or of its authorities, or concerning the delimitation of its frontiers or boundaries. This map has been provided by the authors. 